\title{
Synthesis of Nanoporous $\mathrm{TiO}_{2}$ and Its Potential Applicability for Dye-Sensitized Solar Cell Using Antocyanine Black Rice
}

\author{
Brian Yuliarto, ${ }^{1}$ Wilman Septina, ${ }^{1}$ Kasyful Fuadi, ${ }^{1}$ Fahiem Fanani, ${ }^{1}$ \\ Lia Muliani, ${ }^{2}$ and Nugraha ${ }^{1}$ \\ ${ }^{1}$ Material Processing Laboratory, Engineering Physics Department, Bandung Institute of Technology, \\ Jl. Ganesha, no.10 Bandung 40132, Indonesia \\ ${ }^{2}$ Research Center for Electronics and Telecommunications, Indonesian Institute of Science, \\ Jl. Sangkuriang Kampus LIPI Gd 20 Bandung 40152, Indonesia \\ Correspondence should be addressed to Brian Yuliarto, brian@tf.itb.ac.id
}

Received 21 April 2010; Revised 13 July 2010; Accepted 5 September 2010

Academic Editor: Steven Suib

Copyright (๑) 2010 Brian Yuliarto et al. This is an open access article distributed under the Creative Commons Attribution License, which permits unrestricted use, distribution, and reproduction in any medium, provided the original work is properly cited.

\begin{abstract}
Nanoporous mesostructure $\mathrm{TiO}_{2}$ powders were synthesized by sol-gel method, with $\mathrm{TiCl}_{4}$ as a precursor in methanol solution. The Pluronic PE 6200 of block copolymer was used as the pores template. It was found from XRD measurements, both at $400^{\circ} \mathrm{C}$ and $450^{\circ} \mathrm{C}$ calcination temperatures, that the sol-gel technique yielded the nanoporous $\mathrm{TiO}_{2}$ with anatase phase. Based on $\mathrm{N}_{2}$ adsorption characterization using BET method, the $\mathrm{TiO}_{2}$ samples have surface area of $108 \mathrm{~m}^{2} / \mathrm{g}$ and $88 \mathrm{~m}^{2} / \mathrm{g}$ for calcination temperatures of $400^{\circ} \mathrm{C}$ and of $450^{\circ} \mathrm{C}$, respectively. From small-angle neutron scattering (SANS) patterns, $\mathrm{TiO}_{2}$ samples were observed to have nanoporous structures with pore sizes between $22-24 \mathrm{~nm}$. The $\mathrm{TiO}_{2}$ also have order degree which depends on the calcination temperature. The potential applicability of the resulting $\mathrm{TiO}_{2}$ is confirmed for dye-sensitized solar cell (DSSC), composed of nanoporous anatase $\mathrm{TiO}_{2}$ and natural dye from antocyanine black rice. UV-Vis measurement of dye extracted from the black rice indicated that the antocyanine chelate can propagate into the $\mathrm{TiO}_{2}$ nanoporous network. The short circuit photocurrent density (Jsc) under $100 \mathrm{mWcm}^{-2}$ reached $1.287 \mathrm{mAcm}^{-2}$ with open circuit photovoltage (Voc) of $550 \mathrm{mV}$ and the fill factor of $33.4 \%$. The results show that the hybrid organic-inorganic structures are very attractive for future low-cost devices.
\end{abstract}

\section{Introduction}

The dye-sensitized solar cell (DSSC) is one of the potential candidates for next generation solar cells, because its lowcost material and relatively simple production processes. Different from conventional solar cells whose working principle is based on solid state theory, dye-sensitized solar cell is a photoelectrochemical-based solar cell. Photo absorption is done by dye molecule and charge separation by inorganic semiconductor nanocrystals which have a large band gap, and uses electrolytes for dye regeneration.

One of the commonly used wide gap semiconductor for DSSC applications is titanium dioxide $\left(\mathrm{TiO}_{2}\right)$. Titanium dioxide $\left(\mathrm{TiO}_{2}\right)$ is a semiconductor material which has wide applications in optical as well as electronics materials. This is because $\mathrm{TiO}_{2}$ have remarkable physical, chemical, and optical characteristics. It has attracted increased attention for potential applications as gas sensors [1], metal-oxidesemiconductor field effect transistors (MOSFET) gate dielectric [2], anti-microbial coating [3], pigments [3], solar hydrogen generation [4], and photovoltaic cells or well known as dye-sensitized solar cell (DSSC) [5]. In energy and environmental fields, much research has been done on $\mathrm{TiO}_{2}$ characteristics especially on its applications as a main component of DSSC [3]. For this application, material with large surface area is preferred to increase the contact area. Indeed the nanostructure of $\mathrm{TiO}_{2}$ becomes an important characteristic as well as the pore nanosize. A certain class of nanoporous material emerged from the requirements called mesoporous material, which has pore diameters between $2-50 \mathrm{~nm}$ [4]. This kind of material has attracted much attention because of its wide potential applicability in dye-sensitized solar cells as well as sensor devices [5-10]. 
Mesoporous $\mathrm{TiO}_{2}$ has been developed with various methods, most importantly using organic templates to build porous structures. Synthesis of mesoporous $\mathrm{TiO}_{2}$ was first reported by Antonelli and Ying in 1995 using an ionic alkyl phosphate surfactant as a template with sol-gel method [11], however the resulting material was not pure $\mathrm{TiO}_{2}$ because the phosphate molecules were strongly bonded on to the $\mathrm{TiO}_{2}$ structure. One alternative is to use nonionic surfactants, particularly block copolymers, as a substitute to ionic surfactants. Block copolymers have an advantage of being easily removed from inorganic frameworks by calcination or solvent extraction since the block copolymer only involves $\mathrm{H}$-bonding type rather than the electrostatic interactions found using ionic surfactant [12]. Moreover the properties of block copolymers can be continuously tuned by adjusting solvent composition, molecular weight, or polymer architectures of block copolymers [13].

After succeeding in synthesizing mesoporous material using block copolymer templates, publications related to mesoporous $\mathrm{TiO}_{2}$ has continuously increased, but mostly used titanium alkoxide as $\mathrm{Ti}$ source at aqueous solution [14]. Large amounts of water inside the solution can cause hydrolysis and condensation as well as difficulties in controlling the mesostructure because the alkoxide is highly reactive with water. In this research we firstly, in our knowledge, prepared mesoporous $\mathrm{TiO}_{2}$ using triblock copolymer Pluronic PE 6200 as a template and $\mathrm{TiCl}_{4}$ as a precursor at alcoholic solution. The resulting mesostructure $\mathrm{TiO}_{2}$ powder is characterized by using X-ray diffraction, SEM, and small-angle neutron scattering (SANS) to confirm the nanostructure of materials. The resulting mesostructure $\mathrm{TiO}_{2}$ has a nanocrystalline wall, which is necessary to ensure good electron diffusion [15]. A DSSC using nanocrystalline $\mathrm{TiO}_{2}$ film electrode is then fabricated and a DSSC using visible light sensitisation of a nanocrystalline $\mathrm{TiO}_{2}$ film is developed.

To investigate $\mathrm{TiO}_{2}$ application in a DSSC system, the use of natural dye extracted from antocyanine black rice was investigated. Natural antocyanine from black rice extraction would be used as the dye since the antocyanin has good chemical bonding with titanium dioxide [16]. The I-V curve measurement was performed under direct Xenon HID lamp using multimeter, variable resistor, and pyranometer.

\section{Experimental Method}

The triblock copolymer PEO-PPO-PEO Pluronic PE 6200 $\left(\mathrm{PEO}_{8}-\mathrm{PPO}_{30}-\mathrm{PEO}_{8}, M_{\mathrm{av}}=2450 \mathrm{~g} / \mathrm{mol}\right)$ was supplied by BASF. The titanium tetrachloride $\left(\mathrm{TiCl}_{4}\right)$ precursor was purchased from Merck, and methanol was used as a solvent. To obtain $\mathrm{TiO}_{2}$ paste, polyvinyl alcohol (PVA) was used. The dye was extracted from the black rice. All chemicals were used without further purification.

An initial solution was made by adding 1 gram of Pluronic PE 6200 to 10 gram methanol and stirred for 30 minutes to initiate micelle structure. Then the $\mathrm{TiCl}_{4}$ was slowly added to the solution under stirring for 30 minutes so that the molar ratio of $\mathrm{TiCl}_{4}$ : methanol : Pluronic
PE6200 was $1: 21.7: 0.0408$. The ratios used in the synthesis process are as follow; $\mathrm{TiCl}_{4}$ : methanol:Pluronic PE6200. $\mathrm{TiCl}_{4}$ reaction with alcoholic solution is exothermic and produces large amount of $\mathrm{HCl}$ gas and a collection of chloroalkoxide $\left(\mathrm{TiCl}_{2}\left(\mathrm{OCH}_{3}\right)_{2}\right)[17,18]$. The solutions were then aged for 4 days at $40-45^{\circ} \mathrm{C}$ in a furnace until dry gel was formed. The $\mathrm{TiO}_{2}$ dry gels were then calcined at $400^{\circ}-450^{\circ} \mathrm{C}$ for 4 hours with a heating rate of $5-6^{\circ} \mathrm{C} /$ minute to remove the block copolymer and promote crystallization.

The $\mathrm{TiO}_{2}$ paste was made by mixing $\mathrm{TiO}_{2}$ powder with $10 \%$ polyvinyl alcohol (PVA)/water solution, mixed at $80^{\circ} \mathrm{C}$. After that the resulting powder was ground with mortar to obtain the smooth paste for deposition. The paste was deposited onto ITO conductive glass $\left(\mathrm{In}: \mathrm{SnO}_{2}\right)$ using doctor blade technique with area of $0.855 \mathrm{~cm}^{2}$, then sintered at $450^{\circ} \mathrm{C}$ for 30 minutes. The $\mathrm{TiO}_{2}$ film was then rinsed in dye solution extracted from black rice for about 30 minutes.

The antocyanine dye was derived from Indonesian black rice extraction using organic solvent which is the combination of alcohol, acetic acid, and water with the molar ratio of $25: 4: 21$. The black rice as much as 13 gram was grinded using mortar then dissolved by solvent on magnetic stirrer. Finally, the solid filtrate was removed with filtration paper and the dye was kept in tight and dark bottle to prevent evaporation and degradation.

The conductive glass with platinum layer as a catalyst was put on the top of the $\mathrm{TiO}_{2}$-dye electrode. This platinumconductive glass acted as a counter electrode. The electrolyte for dye regeneration is composed of $0.5 \mathrm{M}$ potassium iodide (KI), 0.05 M Iodine ( $\left.\mathrm{I}_{2}\right)$, and acetonitrile solvent (all obtained from Merck).

\section{Results and Discussion}

Figure 1 shows Thermo Gravimetric-Differential Thermal Analysis (TG-DTA) results for $\mathrm{TiO}_{2}$ dry gel after 4 days aging at $45^{\circ} \mathrm{C}$. The TG-DTA was performed at the temperature range between $50^{\circ}-600^{\circ} \mathrm{C}$ with $10^{\circ} \mathrm{C} /$ minute of heating rate. From the TGA curve, which shows sample weight loss as the function of temperature, the sample weight decreased by about $75 \%$ when heated up to $460^{\circ} \mathrm{C}$. The TGA curve also shows three weight-loss regions. The first region of temperatures below $200^{\circ} \mathrm{C}$ resulted from $-\mathrm{OH}$ groups evaporation. The second region between $200^{\circ}-325^{\circ} \mathrm{C}$ was attributed to organic decomposition. The third region from $325^{\circ} \mathrm{C}$ to $460^{\circ} \mathrm{C}$ is due to residual block copolymer oxidation and decomposition of chlorine bonded to the Ti$\mathrm{OH}$. The TGA curve also shows that the block copolymer was completely removed at calcination temperatures above $450^{\circ} \mathrm{C}$.

The DTA curve clearly shows two peaks, the endothermic peak at region of $100^{\circ} \mathrm{C}-200^{\circ} \mathrm{C}$ which is attributed to solvent evaporation, and broad exothermic peak at $325^{\circ} \mathrm{C}-460^{\circ} \mathrm{C}$ which is attributed to the decomposition of block copolymer and chlorine and phase transformation from amorphous to anatase $\mathrm{TiO}_{2}$. The phase transformation actually starts from $350^{\circ} \mathrm{C}$ [19]. As shown in the full TG-DTA curve, the data from TGA curve correlates directly to the DTA record 


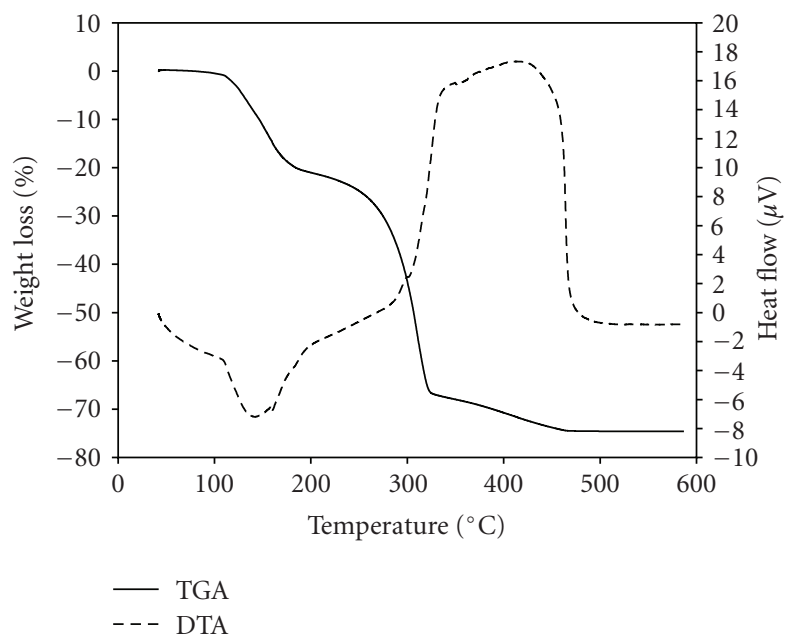

FIgURE 1: TG-DTA results for $\mathrm{TiO}_{2}$ dry-gel where the TGA: full line and DTA: dashed line.

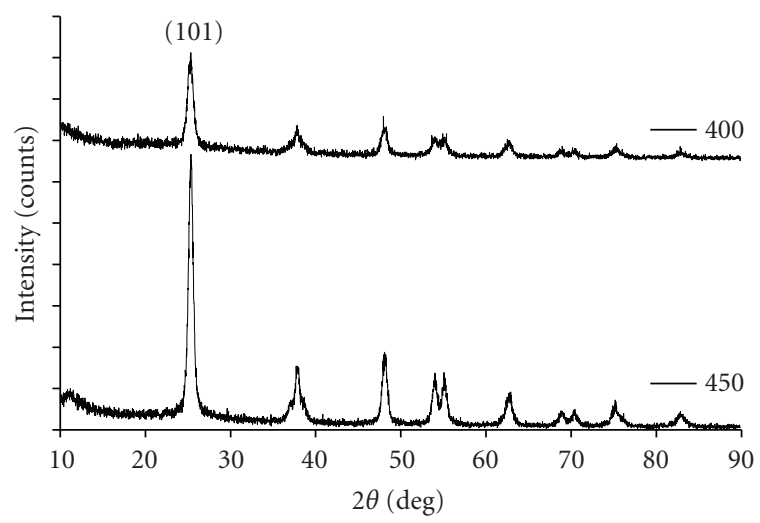

FIgURE 2: Wide-angle XRD patterns of nanoporous $\mathrm{TiO}_{2}$.

since the weight-losses are always followed by endothermic or exothermic processes.

The X-Ray Diffractometer (XRD) patterns were obtained using Philips Analytical X-Ray with $\mathrm{Cu}$ radiation $(\lambda=$ $0.154056 \mathrm{~nm}$ ) and the crystallite sizes were calculated using Scherrer equation at Miller indices (101). Wide-angle XRD patterns shown at Figure 2 indicate both samples have wellcrystallized $\mathrm{TiO}_{2}$ with pure anatase phase according to the JCPDS number 21-1272. As shown at Table 1, higher calcination temperatures resulted in higher crystallite size. More intense and well-resolved peaks observed at higher calcinations temperature indicate the increasing degree of the crystalline. This result correlated with the fact that full crystallization of $\mathrm{TiO}_{2}$ occurs at $550^{\circ} \mathrm{C}$ [20]. In accordance with TG-DTA result, $\mathrm{TiO}_{2}$ sample calcined below $450^{\circ} \mathrm{C}$ still contain some residual carbon, which can be observed from black colour of the powder sample, which in turn may contribute to amorphous peak nature at XRD patterns.

Small-angle Neutron Scattering (SANS) measurements were carried out to confirm the porous structure of the resulting $\mathrm{TiO}_{2}$ at Neutron Scattering Laboratory, BATAN Indonesia using SMARTer. The neutron wavelength of SANS
TABle 1: Properties of Nanoporous $\mathrm{TiO}_{2}$.

\begin{tabular}{lccc}
\hline Sample & Calcinations Temperature & $\begin{array}{c}\text { Particle } \\
\text { size }\end{array}$ & $\begin{array}{c}\text { Surface Area } \\
\left(\mathrm{m}^{2} / \mathrm{g}\right)\end{array}$ \\
\hline Ti-a & $400^{\circ} \mathrm{C}$ & $11 \mathrm{~nm}$ & 108 \\
Ti-b & $450^{\circ} \mathrm{C}$ & $14 \mathrm{~nm}$ & 88 \\
\hline
\end{tabular}

${ }^{\mathrm{a}}$ Calculated from Scherrer equation at Miller indices (101).

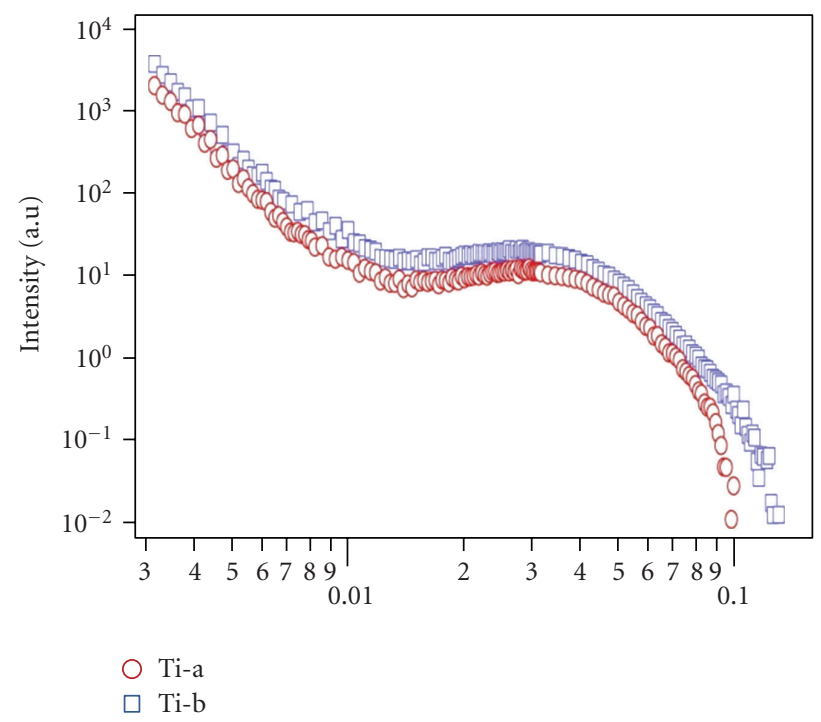

Figure 3: Small-angle Neutron (SANS) patterns of nanoporous $\mathrm{TiO}_{2}$.

was $\lambda=0.566 \mathrm{~nm}$. Sample to detector distances were varied at 2,8 , and 18 meter to obtain the vector of transfer momentum $(q)$ range about $0.02-1.5 \mathrm{~nm}^{-1}$. The SANS patterns as shown in Figure 3 confirm that the correlation peak formed at both samples indicated that mesoporous structures were preserved. The peak formed at low angle can be attributed to the distance between the center of pores [20]. According to the calculations, the average pore distances $\left(d=2 \pi / q_{\text {peak }}\right)$ are about $22 \mathrm{~nm}$ (Ti-a) and $24 \mathrm{~nm}$ (Ti-b) which is typical of the pore to pore distance of mesoporous materials. Average pore distance was increased with increasing calcination temperatures because of structure contraction observed from the heat treatment. SANS patterns also show that the peak intensity of lower calcination temperature sample (Ti-a) was slightly larger. This indicating that sample with lower calcinations temperature has higher pore ordering than sample with higher calcinations temperature (Ti-b).

Scanning Electron Microscope (SEM) images were obtained from JEOL operated at $20 \mathrm{kV}$. The morphology of the samples was observed with SEM images as shown at Figure 4. The structure morphology contains large amount of close packed particles which is typical of porous material. The mesoporosity of samples was partially due to both intrastructure porosity and interstructure porosity of the materials.

Nitrogen adsorption measurements were carried out on a NOVA 1000 High Speed Gas Sorption Analyzer to determine Brunau-Emmett-Teller (BET) surface area. Before 

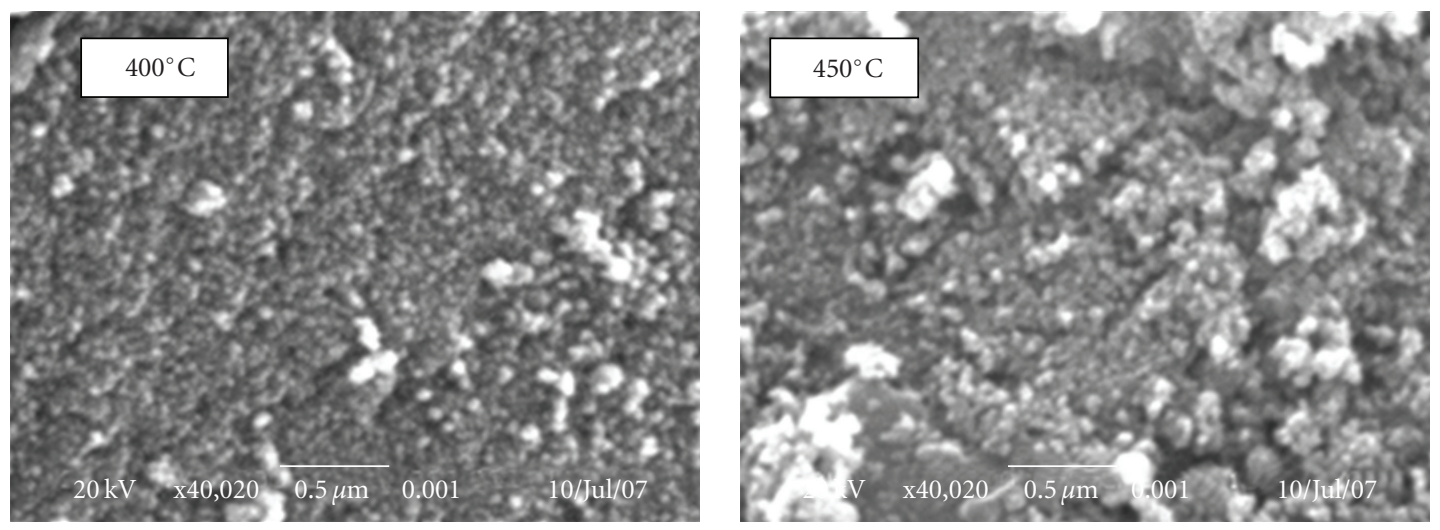

Figure 4: SEM Images of nanoporous $\mathrm{TiO}_{2}$ calcined at $400^{\circ} \mathrm{C}$ and $450^{\circ} \mathrm{C}$.

these measurements, the samples were degassed at $200^{\circ} \mathrm{C}$ for 2 hours in vacuum conditions to eliminate water and oil. According to $\mathrm{N}_{2}$ adsorption measurements, the BET surface area are $108 \mathrm{~m}^{2} / \mathrm{g}$ and $88 \mathrm{~m}^{2} / \mathrm{g}$ for Ti-a sample and Ti-b sample, respectively (Table 1). Higher calcination temperatures produced a lower surface area since the crystallization of $\mathrm{TiO}_{2}$ is usually followed by some collapse and destruction of the mesostructure [21]. These surface areas are larger than commercial Degussa P-25 which is mainly used as a nano $\mathrm{TiO}_{2}$ reference which has BET surface area at about $50 \mathrm{~m}^{2} / \mathrm{g}$ [22].

The DSSC performance of the Ti-a sample was investigated using illumination from a solar simulator. Photocurrent-photovoltage characteristic of the black rice adsorbed on a nanocrystalline $\mathrm{TiO}_{2}$ electrode was measured with a sandwich type cell. The working electrode with the black rice dye adsorbed on a nanocrystalline $\mathrm{TiO}_{2}$ film was gently squeezed together with a platinum-coated ITO glass electrode and irradiated from the substrate side of working electrode. The I-V curve was characterized using a $10 \mathrm{k} \Omega$ potentiometer and digital multimeter (Fluke 77 III and Advantest) to get maximum power output (see Figure 5). Irradiation of $100 \mathrm{~mW} / \mathrm{cm}^{2}$ by a $35 \mathrm{~W}$ Xenon HID lamp was measured using Precision Spectral Pyranometer (Eppley Radiometer) to get the intensity. The fill factor (FF) and efficiency $(\eta)$ are calculated as [1]

$$
\begin{aligned}
& \mathrm{FF}=\frac{\left(I_{\mathrm{max}} \times V_{\max }\right)}{\left(I_{\mathrm{sc}} \times V_{\mathrm{oc}}\right)}, \\
& \eta=\frac{\left(I_{\mathrm{sc}} \times V_{\mathrm{oc}} \times \mathrm{FF}\right)}{P_{\mathrm{in}}} .
\end{aligned}
$$

Figure 6 shows the photocurrent-photovoltage characteristics of a sandwich solar cell based on the black rice dye adsorbed on a nanoporous $\mathrm{TiO}_{2}$ film electrode irradiated with a light intensity of $100 \mathrm{~mW} / \mathrm{cm}^{2}$ as a light source. The $I_{\mathrm{sc}}, V_{\mathrm{oc}}, I_{\max }, V_{\max }$, and the point of $P_{\max }$ also are indicated in Figure 6. The $I_{\max }$ and $V_{\max }$, which indicate the photocurrent and photovoltage at $P_{\max }$, are estimated to be $0.69 \mathrm{mAcm}^{-2}$ and $343 \mathrm{mV}$. The $J_{\mathrm{sc}}$ and $V_{\mathrm{oc}}$ values of solar cell were estimated to be $1.287 \mathrm{mAcm}^{-2}$ and $550 \mathrm{mV}$. The $\eta$ value

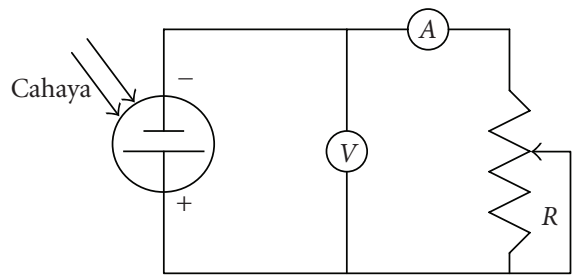

FIGURE 5: The circuit for the measurement of photocurrentphotovoltage characterization of DSSC using black rice adsorbed on a nanocrystalline $\mathrm{TiO}_{2}$ film electrode with $35 \mathrm{~W}$ HID lamp.

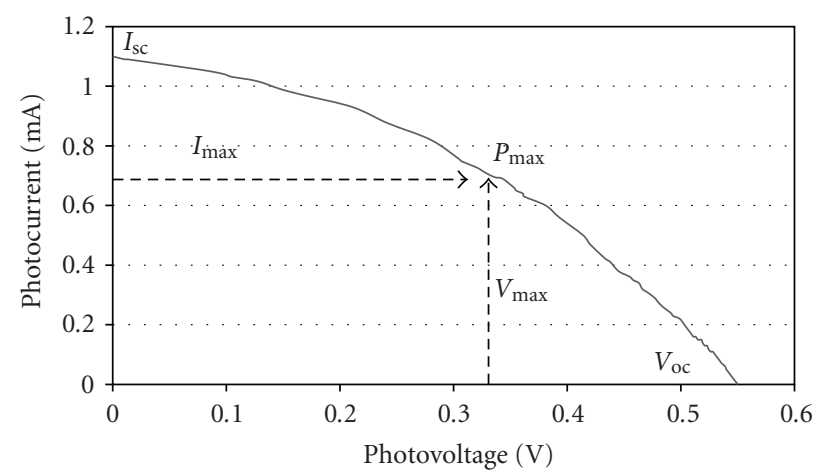

Figure 6: Photocurrent-photovoltage characterization of dyesensitized solar cell using black rice dye immobilized on $\mathrm{TiO}_{2}$ film with 35 W Xenon HID lamp as a light source.

was estimated to be $0.236 \%$ and the $P_{\max }$ was $236.7 \mu \mathrm{Wcm}^{-2}$. The FF value was estimated to be $33.4 \%$ using (1). The low efficiency of DSSC could be caused by the black rice dyes extraction which could be improved by better extraction process such as purification and enrichment.

To investigate the absorption process of sunlight into the black rice dye, the UV-VIS measurement is performed between $200-700 \mathrm{~nm}$ of the wavelength. The Figure 7 shows the UV-Vis absorbance spectrum of black rice dye extract which is characterized by three peaks located at 242, 282, and $530 \mathrm{~nm}$, with absorbance $0.72,0.80$, and 0.62 , respectively (in arbitrary unit). Those peaks indicate the higher possibility 


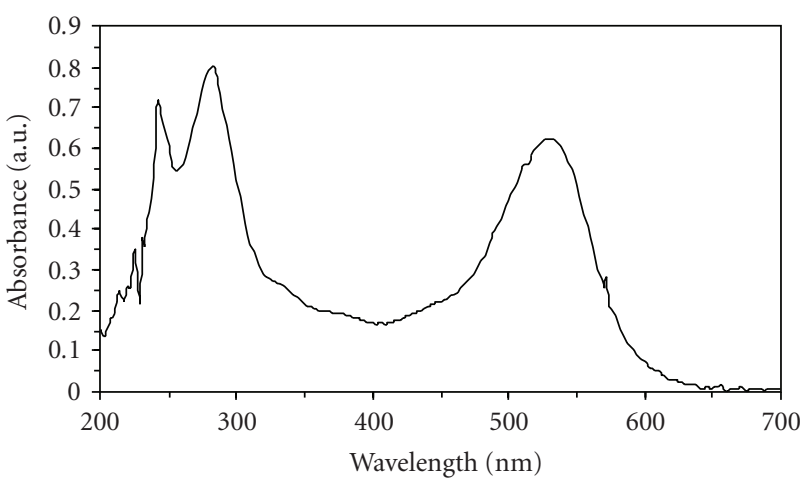

Figure 7: Absorbance spectra of black rice dyes extract.

to absorb sunlight, especially at $530 \mathrm{~nm}$. Because of the peak of sunlight spectra at $550 \mathrm{~nm}$ [1], the dyes can receive maximum sunlight absorption. When the antocyanine dyes from black rice chemically bonded with $\mathrm{TiO}_{2}$, it can be chemical adsorption or chelation as described before; the LUMO-HOMO of dyes will be affected so that the bandgap energy will change. Finally, the changing of bandgap energy will shift the peak of absorbance spectra and broaden the peak. Some reports state that the shifting goes to the lower energy or red shifting $[5,9]$. As a result, the black rice dyes absorbance will approach the sunlight maxima spectra, which yield higher possibility of light harvesting.

\section{Conclusions}

Nanoporous $\mathrm{TiO}_{2}$ with mesostructure anatase wall have been successfully prepared using a combination of sol-gel method and block copolymer as a template. $\mathrm{TiCl}_{4}$ was used as a Ti precursor and Pluronic PE6200 acted well as mesoporous template although only short-range pore ordering is observed. Calcination temperature was observed to be an important parameter for mesostructure formation as well as crystallization process. The biophotovoltaic conversion device based on DSSC using black rice dye adsorbed nanoporous anatase $\mathrm{TiO}_{2}$ film electrode was prepared and the DSSC using visible light sensitisation of a nanocrystalline $\mathrm{TiO}_{2}$ film was developed. The I-V curve of the solar cell using black rice adsorbed on a nanocrystalline $\mathrm{TiO}_{2}$ electrode is characterized under light intensity of $100 \mathrm{mWcm}^{-2}$. It is estimated that $\eta$ value was $0.236 \%$ and the $\mathrm{FF}$ value was $33.4 \%$.

\section{Acknowledgments}

This work has been supported by a grant from HIBAH STRATEGIS NASIONAL DIKTI of the Ministry of National Educations. Authors would like to thanks BASF Indonesia for providing block copolymer PE6200 and Dr. Edy Giri from BATAN-Indonesia for his assistance in SANS characterization.

\section{References}

[1] K. Hashimoto, H. Irie, and A. Fujishima, " $\mathrm{TiO}_{2}$ photocatalysis: a historical overview and future prospects," Japanese Journal of Applied Physics, Part 1, vol. 44, no. 12, pp. 8269-8285, 2005.

[2] B. Yuliarto, I. Honma, Y. Katsumura, and H. Zhou, "Preparation of room temperature $\mathrm{NO}_{2}$ gas sensors based on $\mathrm{W}$ - and $\mathrm{V}$ modified mesoporous MCM-41 thin films employing surface photovoltage technique," Sensors and Actuators, B, vol. 114, no. 1, pp. 109-119, 2006.

[3] M. Grätzel, "Dye-sensitized solar cells," Journal of Photochemistry and Photobiology C, vol. 4, no. 2, pp. 145-153, 2003.

[4] C. T. Kresge, M. E. Leonowicz, W. J. Roth, J. C. Vartuli, and J. S. Beck, "Ordered mesoporous molecular sieves synthesized by a liquid-crystal template mechanism," Nature, vol. 359, no. 6397, pp. 710-712, 1992.

[5] H. Abdullah, N. P. Ariyanto, S. Shaari, B. Yuliarto, and S. Junaidi, "Study of porous nanoflake $\mathrm{ZnO}$ for dye-sensitized solar cell application," American Journal of Engineering and Applied Sciences, vol. 2, no. 1, pp. 236-140, 2009.

[6] N. P. Ariyanto, H. Abdullah, S. Shaari, S. Junaidi, and B. Yuliarto, "Preparation and characterisation of porous nanosheets zinc oxide films: based on chemical bath deposition," World Applied Sciences Journal, vol. 6, no. 6, pp. 764-768, 2009.

[7] B. Yuliarto, Y. Kumai, I. Honma, S. Inagaki, and H. Zhou, "Benzene sensors based on surface photo voltage of mesoporous organo-silica hybrid thin films," Studies in Surface Science and Catalysis, vol. 165, pp. 893-896, 2007.

[8] B. Yuliarto, Y. Kumai, S. Inagaki, and H. Zhou, "Enhanced benzene selectivity of mesoporous silica SPV sensors by incorporating phenylene groups in the silica framework," Sensors and Actuators, B, vol. 138, no. 2, pp. 417-421, 2009.

[9] B. Yuliarto, H. Zhou, T. Yamada, I. Honma, Y. Katsumura, and M. Ichihara, "Effect of tin addition on mesoporous silica thin film and its application for surface photovoltage $\mathrm{NO}_{2}$ gas sensor," Analytical Chemistry, vol. 76, no. 22, pp. 6719-6726, 2004.

[10] B. Yuliarto, H. Zhou, T. Yamada, I. Honma, and K. Asai, "Synthesis of a surface photovoltage sensor using self-ordered tin-modified MCM-41 films: enhanced $\mathrm{NO}_{2}$ gas sensing," ChemPhysChem, vol. 5, no. 2, pp. 261-265, 2004.

[11] D. M. Antonelli and J. Y. Ying, "Synthesis of hexagonally packed mesoporous $\mathrm{TiO}_{2}$ by a modified sol-gel method," Angewandte Chemie, vol. 34, no. 18, pp. 2014-2017, 1995.

[12] G. J. D. A. A. Soler-Illia, E. L. Crepaldi, D. Grosso, and C. Sanchez, "Block copolymer-templated mesoporous oxides," Current Opinion in Colloid and Interface Science, vol. 8, no. 1, pp. 109-126, 2003.

[13] F. S. Bates and G. H. Fredrickson, "Block copolymers-designer soft materials," Physics Today, vol. 52, no. 2, pp. 32-38, 1999.

[14] P. Yang, D. Zhao, D. I. Margolese, B. F. Chmelka, and G. D. Stucky, "Block copolymer templating syntheses of mesoporous metal oxides with large ordering lengths and semicrystalline framework," Chemistry of Materials, vol. 11, no. 10 , pp. 2813-2826, 1999.

[15] M. C. Fuertes and G. J. A. A. Soler-Illia, "Processing of macroporous titania thin films: from multiscale functional porosity to nanocrystalline macroporous $\mathrm{TiO}_{2}$," Chemistry of Materials, vol. 18, no. 8, pp. 2109-2117, 2006.

[16] S. Hao, J. Wu, Y. Huang, and J. Lin, "Natural dyes as photosensitizers for dye-sensitized solar cell," Solar Energy, vol. 80, no. 2, pp. 209-216, 2006. 
[17] G. J. D. A. A. Soler-Illia, C. Sanchez, B. Lebeau, and J. Patarin, "Chemical strategies to design textured materials: from microporous and mesoporous oxides to nanonetworks and hierarchical structures," Chemical Reviews, vol. 102, no. 11, pp. 4093-4138, 2002.

[18] H. Luo, C. Wang, and Y. Yan, "Synthesis of mesostructured titania with controlled crystalline framework," Chemistry of Materials, vol. 15, no. 20, pp. 3841-3846, 2003.

[19] E. L. Crepaldi, G. J. D. A. A. Soler-Illia, D. Grosso, F. Cagnol, F. Ribot, and C. Sanchez, "Controlled formation of highly organized mesoporous titania thin films: from mesostructured hybrids to mesoporous nanoanatase $\mathrm{TiO}_{2}$," Journal of the American Chemical Society, vol. 125, no. 32, pp. 9770-9786, 2003.

[20] E. Lancelle-Beltran, P. Prené, C. Boscher et al., "Nanostructured hybrid solar cells based on self-assembled mesoporous titania thin films," Chemistry of Materials, vol. 18, no. 26, pp. 6152-6156, 2006.

[21] H.-S. Yun, K. Miyazawa, I. Honma, H. Zhou, and M. Kuwabara, "Synthesis of semicrystallized mesoporous $\mathrm{TiO}_{2}$ thin films using triblock copolymer templates," Materials Science and Engineering C, vol. 23, no. 4, pp. 487-494, 2003.

[22] L. Saadoun, J. A. Ayllón, J. Jiménez-Becerril, J. Peral, X. Domènech, and R. Rodríguez-Clemente, "1,2-Diolates of titanium as suitable precursors for the preparation of photoactive high surface titania," Applied Catalysis B, vol. 21, no. 4, pp. 269-277, 1999. 

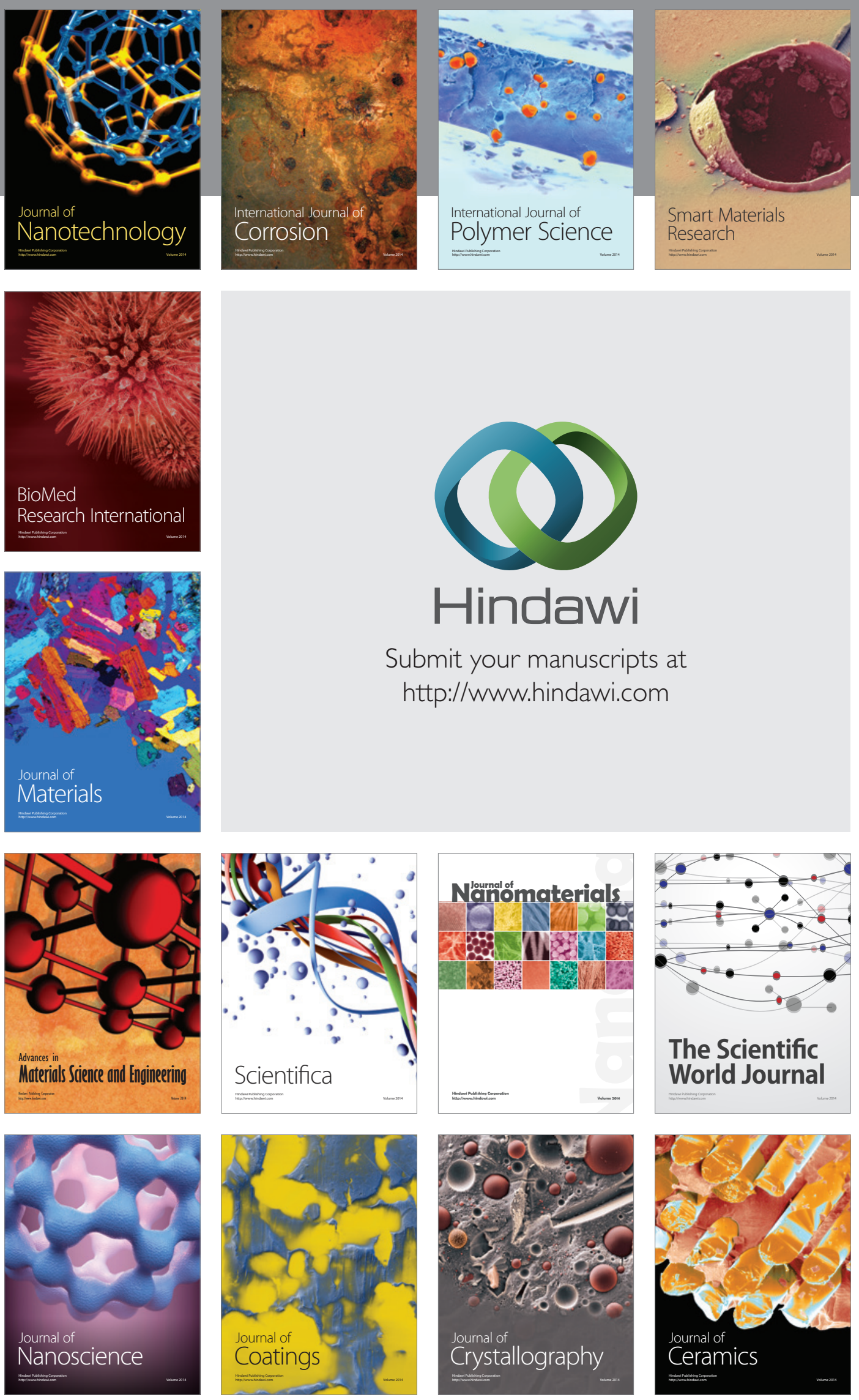

The Scientific World Journal

Submit your manuscripts at

http://www.hindawi.com

\section{World Journal}

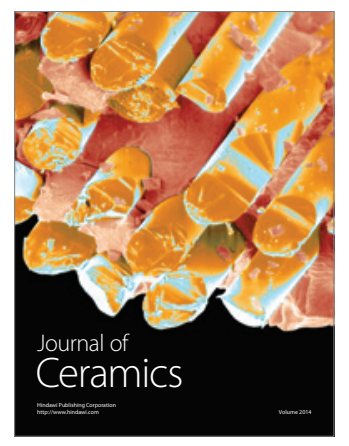

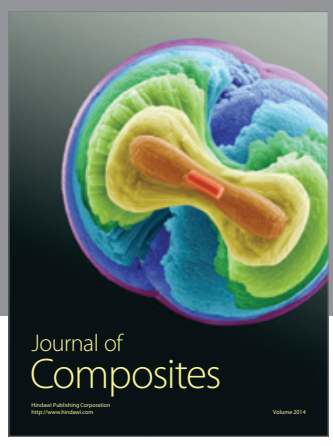
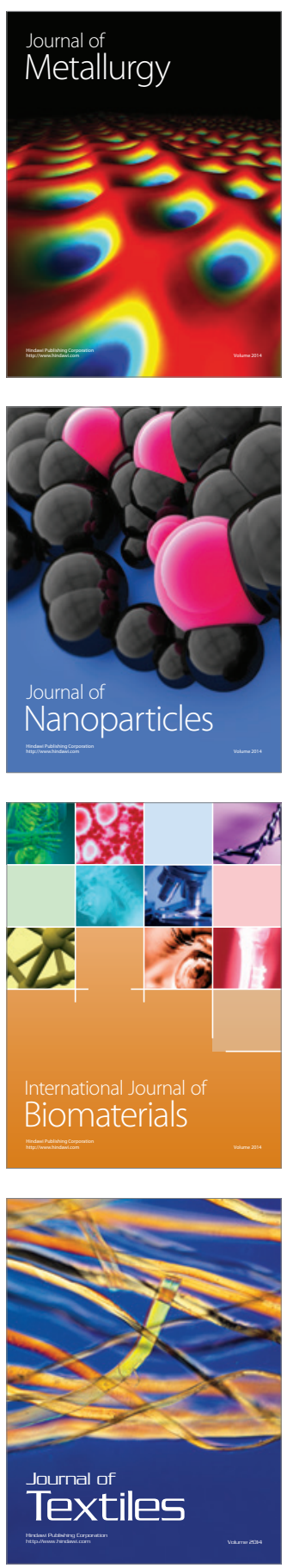